\title{
集落営農形成の意義と戦略的課題
}

平塚 貴 彦

\section{The Significances and the important Tasks on the Formation of the Group Farming based on the Village}

\author{
Takahiko Hiratsuka (Shimane University)
}

The summary of the analysis in this paper is given below.

1. In this paper, the group farming based on the village as the ideal one, namely cooperative one, among various types of the group farming based on the village is investigated. It has the utilization right of farmland. And its management is independent of each individual farm house-hold as a member.

2. The necessity to form the group farming based on the village is increasing. But its position as a farm management is very minor at present.

3. Compared especially with the individual family farm, the group farming based on the village has many economic, social, and public significances. They are as follows : for example, the cost-down and the earnings increase in the village as a whole, the maintenance of the village itself, cultivation of water resources and flood prevention.

4. The important tasks on formation of the group farming based on the village are as follows: (1) ensuring its own successor, (2) progressing the earning power, (3) rationalizing the distribution method of earnings, (4) enlightening a consciousness and making on consensus on formation, (5) adjusting relations between the group farming based on the village and the existing group farmings, machinery and facilities, (6) the various supports by the national government and the local autonomy.

5. In the future with the collapse of the family farms various types of the group farmings based on the village will turn into the cooperative type, and it will turn into the incorporated one. The development directions of various types of the group farming based on the village vary from one agricultural region to another.

\section{1. 問題の所在と課題}

わが国農業の構造問題としての担い手問題は, 経営 体及び農業者・農業労働力の両側面において，稲作な ぞ土地利用型農業に典型的・象徵的に現れている。た とえば稲作経営の多くは職業として成り立たず，展望 が持てないことから，とりわけ若者には魅力のない存 在になっている，それは畜産や施設園芸などと違い， 農業後継者の就農の受血が準備されていないとてろに あ原因がある.

いずれにせよ，乙のままでは農地利用の後退が進 み, 農村地域自体の活力低下・衰退・崩壊の進行が鲧 念され，基礎食料供給力の減退・食料自給率の一層の 低下，そして農業の外部効果の縮小などが若起する.

こうした状況でまさに緊急の課題として，土地利用 型農業の担い手の経営形態やその経営的要件がどうあ
るべきか，担い手育成の方向性と具体的方策が問われ ている，そんななかで, 集落または隣接する複数集落 の範囲で組織化された営農単位, すなわち各家族経営 の衰退・崩壊による農地の荒廃, 農家や集落の崩壊を 防ぎ，「零 細 農地所有一大規模経営」を可能にする土 地利用型農業の日本型樍造改善の多様な担い手の一経 営形態として，集落営農 ${ }^{11}$ が注目されている． その背 景には家族経営単位の規模拡大だけでは, 農業棈造の 改善が容易に進展しそうにないという現状認識が多分 にある.

本報告ではその集落営農を対象に, (1)集落営農の形 態と担い手としての位置, (2)集落営農形成の必要性と 目的, (3)集落営農の経済的及び社会的・公益的な意 義, (4)集落営農が備えるべき要件及び形成上の戦略的 課題, (5)集落営農の展開方向など若干の将来展望につ いて，それぞれ考察する。 


\section{2.＼cjkstart集落営農形成の必要性亡意義}

\section{1 ）集落営農の形態と担い手としての地位}

集落営農という用語は，センサスなどの統計には使 用されていない，一般的には多梯な地縁的営農集団を 含む幅広い意味に使われて㧍り, 農家以外の農業事業 体の 1 つである協業経営体偖属するすのから, 農作業 受託・機械や施設の共同利用・栽培協定・集団転作な どを行ういわゆる生産組織や農業サービス事業体に該 当するものがある。

本報告では前者を協業経営型2)，後者を生産組織型 之呼ぶ. 協業経営型は農家から独立した経営体で，農 地の所有権及び事実上の利用権を有し，経営主宰権を 持っており, 法人格を持つものと法人格を持たない任 意組合形態のものがある ${ }^{3}$. 一方，生産組織型は，農 家の農業経営を補完する組織体で，経営主宰権は農家 にある。そして本報告では協業経営型集落営農（以 下，集落営農之呼ぶ）を考察対象とする，また，生産 組織型に比へて担い手としての量的地位が低い協業経 営型を対象にするのは，それが経営主宰権を持ったよ り高次の主体性を持つ担い手であることに加え，生産 組織型が補完する多くの家族経営の崩壊（家族協業体 制の崩壊）が今後一層進行し，それの協業経営型への 転換を展望するからである.

さて，1990年センサスによると水稲を収穫した農家 以外の農業事業体数は全国に763あり, 収穫面積シュア は $0.35 \%$ ，そのうち協業経営体は 583 , 収穫面積シュア は $0.28 \%$ ある. これはたとえば水稲収穫面積 5 ha以 上農家の面積シェア $5.96 \%$ 亿比べてもな挌段に低 い，そして，乙れら農業事業体のすべてが集落営農で はないため, 協業経営型集落営農のシェアはさらに小 さいといえる，ただ，実際は農業経営を行っていて 屯，機械利用組合などの名称で生産組織に分類され， 協業経営体に分類されていないあのああろうが，大勢 に影響はないだろう。

一方，その多くが生産組織である農業サービス事業 体は，水稲を対象とするすのが全国に11,7064あり， 水稲の全作業之耕起・代かき, 田植・稻刈り・脱穀の 3 作業平均の受託面積は, 全国水稲収穫面積の $4.44 \%$ を占めている ${ }^{5}$ ．乙れは，前述の農家以外の農業事業 体のシェアの10倍以上であるが， 5 ha以上農家のそれ よりは低い。

\section{2 ）大規模農家形成の一定の限界亡集落営農形成の 必要性}

土地利用型農業構造改善の中心的担い手である 5 ha 以上の農家は次第に増加しているが，そのシェアは依 然低い，たとえば1990年センサスによると，水稲収檴 面積 5 ha以上の農家は，全国で戸数シェア $0.61 \%$, 面 積シェア5. $96 \%$ である．都府県ではそれぞれ $0.22 \%$ ， $2.34 \%$ とさらに低い.

中核農家（基幹男子農業專従者のいる農家）や自立 経営農家に農地を面的に集積することは現段階では容 易ではない，それは貸付希望農地をまとめて団地化し て借手に集積する何らかの農地利用調整システムが整 備されていないととに加え, 農地を貸付けて非農家に なることで集落内でのステイタスが低下することや特 定の農家に集落の農地の大部分を貸付けるととに一般 農家の抵抗感がなお根強いととなど，多様で複雑な要 因があると考えられる，そのため，農地の賃借は基本 的には 1 筆ごとに相対で行わ机分散錯围の欠陷を克服 できていない，それどころか借手の絶対的不足下で， 借手と貸手のミスマッチが発生し, 農地利用の後退を あたらしている，また，借手による規模拡大むたとえ ば 5 ha以上の作付面積になると規模の経済を十分発揮 するに至っていない6).

こうした農業構造下では，そこから派生する耕作放 率地や不作付地の增加に象徴される諸問題を解決する 一方策として, 集落営農の形成が期待される.なぜなら 零細分散錯围状態の農地所有下での団地的農地利用を 伴った大規模経営は，まずは農家の合意形成が比較的 容易な “集落”に扔いて集落営農形態で形成されるの がごく自然な方向であると考えられるからである7 .

そてで集落営農形成の目的あるいは必要性を整理す ると以下の 3 つ要約される8).

第 1 は，農業所得の向上によって参加農家の総所得 の增加を実現するとともに，集落の農業を中心的に担 う人材の経済的自立を集落全体で支援する.

第 2 は, 集落の農業生産と農家生活の基礎資源であ る農地を守り, 農業の維持発展を図って集落を定住可 能な地域社会として存続させる．乙れはとくに中山間 地域で重要な位置を占める.

第 3 は，広く国民経済的観点加消費者利益を高め るため，大規模経営（集落営農もその一形態）を形成 して高生産性・低コスト農業を実現し，国際競争力を 高めつつ食料の安価かつ安定供給を図る。乙れはおお む亦農業構造政策のねらいでもある9

これらのうち集落営農及びその参加農家は第 1 と第 2 を意織して抢り, 定住・くらしの観点が強く反映され 
表 1 協業経営体の経営構造

\begin{tabular}{|c|c|c|c|c|c|c|c|c|c|c|}
\hline & \multicolumn{6}{|c|}{ 水稲作付規模別 } & \multicolumn{3}{|c|}{ 組 織 類 型 別 } \\
\hline & & 平均 & 5 ha未満 & $5 \sim 10$ & $10 \sim 15$ & $15 \sim 20$ & $20 h a \sim$ & $\begin{array}{l}\text { 専 } \text { 業 } \\
\text { 農家型 }\end{array}$ & $\begin{array}{l}\text { 集 落 } \\
\text { 営農型 }\end{array}$ & 中間型 \\
\hline \multirow{7}{*}{$\begin{array}{l}- \\
\text { 組 } \\
\text { 織 } \\
\text { 当 } \\
\text { た } \\
り\end{array}$} & 農業就業者(人) & 28.6 & 12.4 & 18.5 & 22.5 & 15.5 & 76.4 & 9.7 & 60.2 & 23.0 \\
\hline & 構 成 員 & 27.0 & 11.4 & 15.8 & 20.4 & 14.9 & 75.1 & 8.2 & 57.5 & 22.6 \\
\hline & S 男 & 16.1 & 8.5 & 9.2 & 16.4 & 8.4 & 39.8 & 5.0 & 33.4 & 14.5 \\
\hline & $\{$ 女 & 10.9 & 2.9 & 6.6 & 4.0 & 6.5 & 35.3 & 3.2 & 24.1 & 8.1 \\
\hline & 年 & 1.6 & 1.0 & 2.7 & 2.1 & 0.6 & 1.3 & 1.5 & 2.7 & 0.4 \\
\hline & \{男 & 0.9 & 0.5 & 1.3 & 1.5 & 0.5 & 0.6 & 0.8 & 1.5 & 0.4 \\
\hline & 女 & 0.7 & 0.5 & 1.4 & 0.6 & 0.1 & 0.7 & 0.7 & 1.2 & - \\
\hline \multirow{5}{*}{$\begin{array}{l} \\
\text { 組 } \\
\text { 織 } \\
\text { 当 } \\
\text { た } \\
\text { り }\end{array}$} & 世 帯 数 & 18.9 & 9.4 & 9.1 & 17.1 & 16.8 & 46.0 & 7.2 & 39.3 & 14.6 \\
\hline & 専業 & 2.9 & 1.4 & 2.7 & 4.3 & 1.5 & 4.4 & 2.2 & 4.9 & 1.4 \\
\hline & I 兼 & 3.5 & 1.5 & 1.5 & 3.8 & 2.6 & 8.9 & 1.0 & 7.4 & 3.3 \\
\hline & II 兼 & 11.2 & 6.5 & 4.4 & 7.3 & 11.9 & 28.7 & 3.6 & 24.1 & 8.9 \\
\hline & 非農家 & 1.3 & - & 0.5 & 1.7 & 0.8 & 4.0 & 0.4 & 2.9 & 1.0 \\
\hline \multirow{2}{*}{$\begin{array}{l}\text { 水面 } \\
\text { 稲 } \\
\text { 作 (a) } \\
\text { 付 }\end{array}$} & $\begin{array}{l}\text { 農業就業者 } \\
1 \text { 人当たり }\end{array}$ & 52.2 & 28.8 & 42.3 & 53.5 & 109.1 & 47.6 & 137.0 & 34.2 & 44.3 \\
\hline & $\begin{array}{c}\text { 一世帯当たり } \\
\text { (非農家を除く) }\end{array}$ & 84.7 & 38.0 & 91.0 & 78.2 & 105.7 & 86.7 & 195.4 & 56.5 & 74.9 \\
\hline
\end{tabular}

資料：農林水産省『平成 2 年産米生産費調査』より作成.

注：1）専業農家型

オペレーター農家 (世帯) が複数戸集まり, 共同で組織内外の作業を行っており，オペレーター農家 (世帯) 数が構成員のおおむね 8 割以上の組織をいう.

2) 集落営農型

集落内のおおむね 8 割以上の農家（世帯）が集まり，そのうちのオペレーター農家（世帯）を中心として共同 出役により組織内の作業を行っている組織をいう.

3) 中間型

複数戸の農家 (世帯) が集まり, そのうちのオペレーター農家 (世帯) を中心として組織内外の作業を行って いる組織をいう。

る.一方，第 3 は国の構造政策的観点から需給事情を 反映した価格政策, すなわち市場原理の導入などと深 く連動している，そして今日の農業問題に対する経済 界等の世論は第 3 の考えに偏向しており, 第 1 , 第 2 と相容れないという大きな問題がある.

\section{3）集落営農の経済的意義}

\section{(1) 集落営農の経済性}

集落営農の生産費等の経済性を他の協業経営体や大 規模農家のそれと比較してみよう（表 2 参照）ままず, 生産費は大規模農家は $10 \mathrm{ha}$ 以上が上昇し, 規模の経済 はみられない，協業経営では20haまでは低下するが20 ha以上で上昇している. 協業経営を組織類型別に表 1 とも併せてみると, 集落営農型は他類型より規模は大 きいが，とくに専業型に比へて高く，中間型と比べて あそれほど優ってはいない。

このように, 表 2 をみる限り大規模農家では10ha, 協 業経営では20haに規模桩大のカべがありそうだが, 協 業経営の場合はむしろ類型の違いか規模に反映してい るとみられる。

つぎに10 a 当たり所得・労働報酬，1日当たり労㗢
報酬で収益性をみると，大規模農家も協業経営屯規模 の経済が認められず，とあに最上層の低位が目立って おり, 協業経営では集落営農型がとくに低い。

\section{（2）集落営農化の経済効果}

集落営農の経済性は, 上述のように大規模農家や他 類型の協業経営に比べ決して高くはない. しかし参加 農家当たり規模は小さいが, 組織体としての経営規模 は大きく, 参加農家数や農業就業者数は多い.したが って, 大規模農家や他類型の協業経営より屯集落営農 の方が地域の農地面積を面的により多くカバーし, 土 地利用型農業の構造改善, 地域農業の維持, そして地 域定住条件の確保などへの貢献度はより大きいとみら れる.

ここでは集落営農か形成された場合の経済効果を, 各農家が自己完結的傜作経営を行っている場合と比 較試算する. 表 3 は, 表 1 , 表 2 の集落営農型協業経営 之参加農家平均に相当する『米生産費調查』のデータ を使って試算した結果である，同表によると，農家毎 の経済効果はもとより, 集落全体として大幅な費用節 減, 労働時間節減 (余层創出), 付加 価值増加の効果 


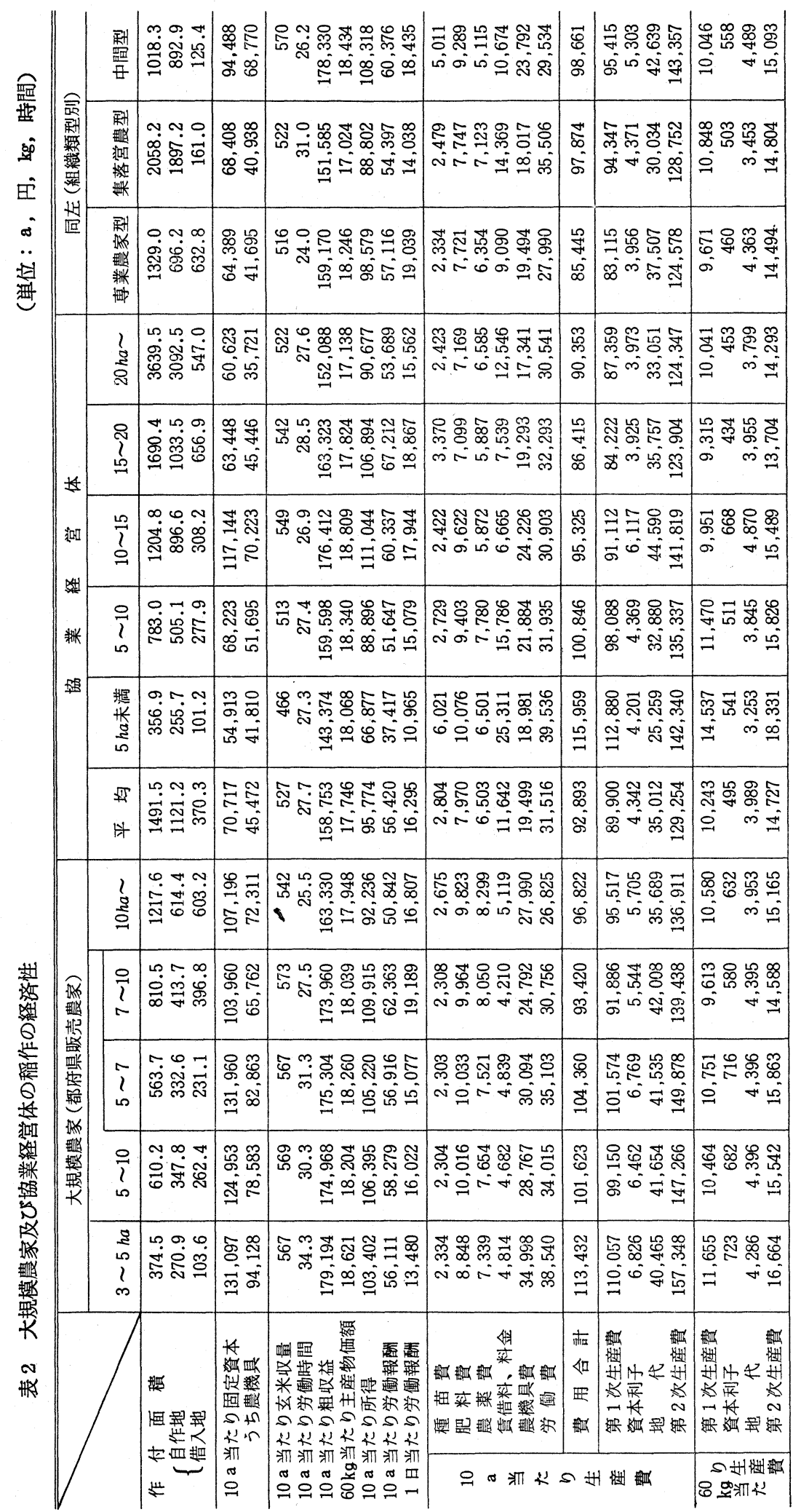


表 3 集落営農化による経済効果の試算 (単位：時間，円，\%)

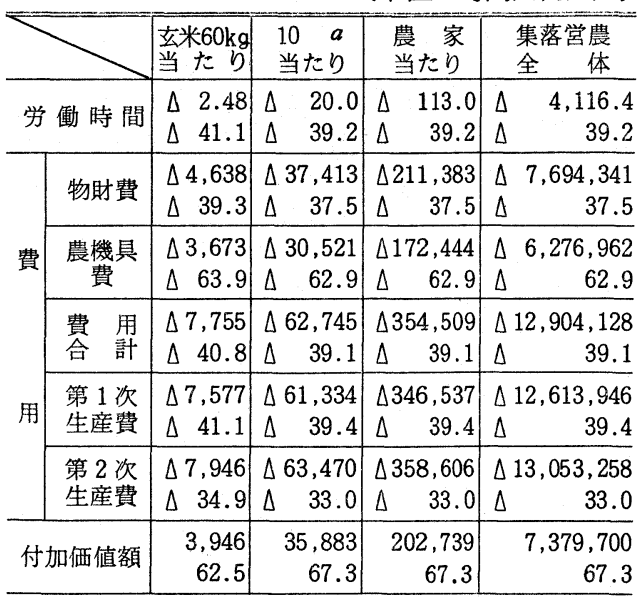

資料：農林水産省『米生産費調查 (平成 2 年産)」より作成 注 : 1) 農家数 36.4 戸, 水稲作付面皘 $2,058.2 \mathrm{a}$, 平均 56.5 a の集落 (表 2 の集落営農型参照) が各農家自己完結 型の農業構造加ら集落営農型協業経営に変化した場合 を想定している。

2) 自己完結型農家の数值は都府県全調查農家 $0.5 \sim 1.0$ ha層 (平均 $71 \mathrm{a}$ ) のあのを使用. 集落営農は表 2 の協 業経営体の集落営農型の数値である。

3）各項目の上段は実数，下段は増減率（\%）を示す。

4） $\triangle$ 印は減少を示す.

5) 付加価值額 $=$ 粗収益 - (費用合計一労働費)

があたらされるてとを示している.なかであ付加価值 増加率と農機具費減少率が目立って高く, 後者が前者 に大きく寄与していることもわかる.

\section{（3）集落営農の経済的意義}

てれまでの考察結果もふまえ，集落営農がもたらす 経済的意義を整理しておてう ${ }^{10)}$.

第 1 亿, 経営及び作業の面積規模が拡大し, 農地利 用の団地化す実現する．乙れは経営の零細性と農地の 分散性の同時克服であり, 参加農家率が高いほど効果 あ大きい，現段階ではそれが容易ではない家族経営に 対する集落営農の有利性であある.

第 2 に，農地の借手と貸手のミスマッチや借手不足 などによる耕作放棄や荒らし作りの回避, 農地の維持 之高度利用がむたらされる．転作の団地化や裏作麦な どの導入による経営複合化効果も得られる.

第 3 に，機械・施設の適正装備之効率的利用によ り, 自己完結家族経営の場合の不経済が解消する.

第 4 に，栽培技術や栽培管理の高位平準化が進み， 集落全体の単収向上や農産物の品質向上が期待され る.
第 5 に, 集落の農地が特定の農家に集積されると, 共同作業や賦役の形で維持管理されている農道や用排 水路等にかかる社会的費用が顕在化するが, 集落営農 ではこの問題は回避される ${ }^{11)}$.

以上の各種の意義の集積結果として,さきの表 3 亿 示したように，大幅な労働時間や費用の節減，そして 付加価值の増加が面的拡がりを伴って発現するのであ る. また，乙れらの経済的成果が, 集落の農業や集落 自体の活性化に生かされなくてはならない．

\section{4）集落営農の社会的・公益的意義}

農村では農地が耕作され農業が健全に営まれるとと が，地域社会としての集落を維持・活性化するための 基礎的要件である.

ところで, 今日家族経営の多くが崩壊しつつある が，それに代わる新しい担い手が形成されていないた め集落自体が崩壊の危機们直面しているとてろ屯少な くない．とうした事態は農業の多面的な公益的機能の 維持にあ支障をきたすのである.

こてでは, 農村地域社会の維持・活性化, 農業の公 益的機能の維持といった側面から, 集落営農があたら す社会的・公益的意義を考察する ${ }^{122}$.

第 1 亿，もともと集落営農のねらいは異質な農家を 包摂し, 参加農家全体の経済的利益を高めるととにあ るが，集落営農の形成と存続それ自体が集落の定住条 件を維持する効果を発揮する. 乙の社会的意義の重要 性は，とりわけ中山間地域では経済的意義のそれを超 えるといってよい。

第 2 亿, 集落営農の形成過程及び形成後の管理運営 についての話合いのなかで，集落内の連帯意識や相互 協力精神が高揚し, 集落機能か強化される. また, 農 業労働力の不足・高龄化で耕作できない農家む維持・ 管理され，集落の社会的安定性と活力が高まる.

第 3 K, 農道・農業用排水路・畦畔等が共同作業や 賦役の形で維持管理されているので，農村の景観之環 境の保全に役立ち, 人々に快適感之安心感, そして集 落活性化への意欲と自信を与える.

第 4 亿, 農業学働時間の大幅節隇は, 農家の就業選 択の幅を広げる. たとえば農業は主として男性が担う 労働組織を形成し，女性は自由な就業選択をすること 屯可能になる. これは農家後継者のいわゆる嫁不足の 解消, すなわち農家後継者の確保, したがって集落の 維持にあ役立つ.

第 5 に，集落営農の形成で稲作など土地利用型農業 が守られるので, 水資源の保全とかん養, 洪水や土砂 
崩れの防止, 都市住民等の保養・レクリエーション・ 交流の場の確保・提供など農業の多面的な公益的機能 あ維持される.

\section{3. 集落営農の要件と形成の戦略的課題}

\section{1）集落営農の要件}

\section{(1) 後継者確保の要件}

集落営農が長期持続的に発展するためには，管理運 営の中心になる優れた人材が必要である. それはリー ダーとか経営者と呼ばれ，多くは中高年であるが，結 局はその後継者を確保できるかどうかが集落営農の将 来を左右する．集落営農における経営者の後継者は, たとえば最初はオペレーターとして就農し，次第に経 営者能力を修得していくことになるが，優れた潜在能 力を持った若者が後継者として就農するかどうかは， 集落営農がどれだけ就農したがって職業としての魅力 を備えているかである．その意味で集落営農が備える べき主な要件を検討しよう.

第 1 に，後継者に少なくとも地域の社会的平均的水 準の生涯所得が保証され, 休日の確保, 社会保険（年 金・健康・労荻・雇用保険など）の適用などが必要で ある.

第 2 に, 経営者としてとくに革新的能力を十分発揮 できる環境を準備し, 参加農家以外の人材の参入にも 道を開くことが大切である.

第 3 に, 集落営農の管理運営が企業的・近代的な契 約関係を基本に行われる体制が求められる，そのため 企業形態を集落営農の発展段階に応じて任意組合，農 事組合法人，有限会社の中から適切に選択し，固定化 せずに若者にとってより魅力的な形態に転換する必要 がある.

第 4 に，後継者が孤独にならないように，同じ集落 営農内または周辺集落等に仲間を確保しなくてはなら ない. そのため小規模な集落では複数集落単位の集落 営農を形成するとか，地域内に多くの集落営農を形成 する必要がある.

第 5 に，集落営農の経営者という職業の社会的・経 済的な客観的評価が，少なくと屯地域の一般勤労者と 同等以上でなくてはならない. この客観的な職業イメ 一ジは上述の諸要件の整備によっても高められるが, 配偶者確保などとも深くかかわっており，農業・農業 経営者の役割などの正しい理解を求めて広く社会啓発 活動を展開することあ必要である.

以上の他に収益力の確保 - 向上, 収益分配の適正化
が基礎的要件として要重で，乙れらは以下に項をあら ためて考察する.

(2) 収益力の確保・向上

集落営農が持続的に発展するためには後継者を年間 雇用し, 参加農家やオペレーターの労働と農地用役に 市場価格での適正な代価を支払い，役員にあ一定の報 酬を出し，少なくとも機械・施設の更新のための内部 保留が可能な収益力の確保と，その安定的向上が必要 である。

表 2 の集落営農型協業経営の全労働報酬は約 11,196 千円，総労賃分配額は約 7,308 千円で差引剰余金は約 3,888 千円となる. 現状はほぼ全員参加型であるが， 今後てれが次第に專業農家型へ移行すれば，労働が常 雇のオペレーターなどに集中するので複数の後継者雇 用す可能になる. しかし, 集落営農型は他の類型に比 べて，規模が大きく，農機具費と支払地代は少ないと いった優位も, 単収と販売単価が低く, 労働時間と借 賃料金が多いために生かされず，生産費と収益性でと くに専業型に及ばない. それだけに経済性向上の余地 あ大きいといえる.

以上の稲作部門にたいして，転作部門は奨励補助金 が漸減するなかで，経営採算性を確保できるかどうか が問題である，農機具費，施設費，地代などの固定費 を稻作との間で分担する部分む多いので複合経営とし ての採算性判断む必要である.

また，後継者やオペレーターを年間雇用するために は収益の絶対額の増大が必要で, 経営の合理化や複合 化のほか周辺集落からの経営受託や作業受託を進める など，広域的な経営展開を図ることも大切である。

\section{（3）収益分配の適正化}

収益分配は集落営農の管理運営上最むむずかしい問 題の 1 つである.乙こでは地縁集団的性格の強い集落 営農が, 後継者にとって魅力的な企業的経営体への変 革を目指す場合の収益分配適正化の方向を考察する.

第 1 は, トレードオフの関係にある農地用役と労働 （経営管理，オペレーター労働を含む）への分配の調 整である. これは基本的には農地用役と労働のそれぞ れの市場需給関係の相対関係, すなわちどちらの生産 要素がより不足しているのか, また将来より不足する のかで判断されるべきである. 一般的には農地用役よ り屯労働（とくに若年労働力の）がより不足してお り，その傾向は今後一層強まるので労働を重視すべき である.ちなみに近年，水田の実勢小作料や田の標準 小作料は全国的に低下している ${ }^{13)}$. 
第 2 は，平等原則が依然重視されて労働の質がほと んど考慮されない労働分配方式に，貢献原則を導入す ることである. 現在の50～60才台の役員 (経営者) や オペレーターは, 多くが兼業就業と両立させながら平 等原則を甘受して半ば献身的に就農している。かれら は集落の和や参加農家の平等性というむらの論理を重 視する性向か強いともいえる.

しかし，かれらに続く若い後継者を経営者やオペレ ーターとして確保するためには, 企業経営のように貢 献原則を導入し，かれらが企業者能力を十分発 揮で き，それが適正に評価されるような分配方式を採用す る必要がある.

集落営農の農作業のうち, 各参加農家が行う水管理・ 畦畔草刈りなどのオペレーターによる機械作業以外の 労働には農外臨時雇賃金並みの支払でもよいが，かれ らにはそれではすまない. なぜなら職業選択の幅が広 いかれらの主観的な労働力供給価格は, 単に年々の所 得ではなく社会保障等を含めた周辺地域の平均的勤労 者, たとえば農協職員並みの平均的生涯所得であるか らである。

以上，収益分配適正化の方向は，いわゆるむらの論 理・平等原則・農地重視から, 徐々に経営の論理・貢 献原則・労働重視へと転換していく必要がある. 換言 すれば，いえやむらのしがらみ，非企業的な経営体質 から脱皮して企業的経営管理システムを備えた，後継 者に魅力的な経営体への変革である. それは結局, 参 加農家が集落営農形成の目的・必要性, とりわけより 高次で共通のそれである「地域社会の維持」の意義を 十分認織・評価し，その実現のために上述の収益分配 適正化への意織改革と組織内合意形成ができるかどう かにかかっている。

\section{2 ) 集落営農形成の戦略的課題}

\section{（1）農家の意識啓発と合意形成}

平成 2 年度の農業白書によると, 今後の地域農業の 担い手について，多くの地域 (集落) で合意形成がで きている市町村は $3 \%$ に過ぎず，一部の地域（集落） はできている $(42 \%)$, 合意形成ができている地域 (集落)はない (55\%) とする市町村が多い14).

この実態は近年多くの農業集落で集落機能 が 低下 し, 問題解決への活力が失われているととを物語るも ので, 集落営農形成への内発的エネルギーは弱い. こ うした集落で集落営農形成への合意形成を図るには, 市町村・農協・土地改良区・農業委員会・普及所など の外部リーダーが, 農家に意識啓発, 助言, 指導など
を積極的に行い，その過程で内部リーダーを育成する ことが必要である.

外部リーダーは，まず農家に対して前述のような集 落営農形成の目的や必要性を，ついで集落営農の多面 的な意義を具体的に示し，十分理解を深めさせる活動 を展開する必要がある.

集落営農の多面的意義を，たとえば表 3 のように数 字化できるものは試算して具体的に示し, 理解度を高 める努力が必要である. 零細な自己完結経営の不経済 な実態, 現状延長線上の集落の農業と社会の将来予測 などを，総合的に分析しその結果を提示するととも に, 現状及び将来の諸問題を解決する基礎的手段とし て集落営農が位置づけられ，参加農家率が高いほどそ の意義が増大することを認識させなくてはならない.

こうした農家への働きかけにより，集落営農形成へ の気運が生まれ, 内発的エネルギーも醸成されて内部 リーダーが出現してくれることが集落合意形成への出 発点である.

（2）既存の集落内農業組織等亡の調整

集落営農の形成は白紙に絵を描くようにはいかな い. 集落には多様な集団が重層的に存在し, 複数集落 に関わっている集団ああろう. 独自に規模扗大を指向 している農家もあろう. 機械や施設もすでに農家や集 団に装備され，利用されている．集落営農の形成に際 しててれらとの関係調整が必要である.

まず生産組織等は，集落営農との間で相互に補完機 能を発揮できるものを除き集落営農に統合し, 集落営 農の規模の経済を十分発揮させるべきである. 一方, 中核農家はできるだけ集落営農の中心的担い手に位置 づけ，農業に専従して経済的に自立できるようにオぺ レーターなどとして参加を求める必要がある.

つぎに既存の機械や施設のうち処分が必要なあの は, 農協が公正に評価し, 集落営農が必要なものは買 取るか借りあげ，不要なものは農協が他の農家等へ売 却を斡旋するなどの協力が必要である.

\section{（3）国及び地方自治体の支援策}

\section{(1) 機械・施設等の更新に対する補助}

協業経営や生産組織等が機械・施設を導入する場 合, 初回に限って半額補助がある. 家族経営に代わる 担い手を育成するため，とりわけ傾斜地や条件不利な 直場の多い中山間地域の集落営農等には, 更新時も半 額補助が可能なように制度改善が望まれる。 あとより 集落営農等も更新時に備えて正規の減価償却を行うへ きであるが，この支援策は若い後継者を確保するため 
の間接的な事実上の所得補助にあなるのである.

\section{(2) 広域的転作受委託に対する支援}

集落営農に限らず稲作経営にとって転作の対応は重 要課題である. 集落営農の場合, 比較的団地化し易い が，一律減反の弊害を除去するためにあ集落や旧村だ けでなく市町村を超えて転作受委託を実施すべき時期 にきている．そして広域的な団地化転作の受委託に対 しては，転作を実施する受託者に奖励補助金を上乗せ する支援策が必要である. 集落営農が委託者になるか 受託者になるか, いずれにしてあ経済的効果は大き い. また，広域的転作受委託は，広域農協合併を契機 に展開の可能性は高まる筈であり，その推進は広域合 併農協の課題であある.

\section{(3) 集落営農形成目標の設定と担い手育成施策の 一元化}

各市町村は集落営農の形成を担い手育成計画の一環 として位置づけ, 具体的な育成目標を明示し, 普及所 や農協との協力体制のもとに推進する必要がある．そ のためには農地保有合理化法人の設置など農地利用調 整機能の強化む不可欠である. 集団営農の形成は, そ れぞれの集落の事情をふまえて生産組織の形成加ら始 める方法あある. いずれにしてあすでに指摘したよう に外部リーダーの役割が大きい.

また，県．市町村などが実施している担い手育成に かかわる施策は数多く，しばしば現場では類似のもの が別ルートで降りてきて繁雑で効率も悪い事例がみら れる. これを整理・一元化し，効率的な担い手育成施 策体系を構築する必要がある.

\section{(4) 後継者確保のための所得補助}

近年, 中山間地域の農家に直接的な所得補助を行う べきだとの論議が高まっているが，乙れには様々な困 難な問題が多く実現は容易ではない15)，そてで，集落 営農などの集団型担い手や法人経営（1戸1法人を含 む）の後継者を対象に，年間雇用契約の屯とに就農す る場合, 就農前に一定の研修期間を設けて一定額の研 修費を貸与し, 就農後一定期間を経過すれば返済を免 除する事実上の所得補助を行う方法あ有効である ${ }^{16)}$.

そのほか, 集落営農などの後継者を地域社会の担い 手としてむ位置づけ，国や地方自治体が集落営農など の経営体に人件費の一部を助成する方法も検討すべき である．乙れは農業政策ならびに地域政策の一環とし ての人材確保ならびに雇用促進対策であある.

(5) 農業政策と総合的な地域政策の連携

集落営農の形成・持続的発展には，その集落及び周
辺地域の定住条件が確保され, できるだけ多くの農家 が定住していることが必要である.乙れはとりわけ中 山間地域において重要である.

そこで第 1 亿, 農業生産基盤の整備は, 単に農業政 策としての経済効率基準だけでなく，定住促進・地域 社会の維持といった地域政策的な観点から実施の是非 が判断されなくてはならない.これらインフラの整備 率は中山間地域ではとくに劣っており, それを平地並 みに引き上げるための整備は地元・受益者負担ゼロで 行うべきである17).

第 2 亿, 若者・後継者の定住に不可欠な生活環境の 整備として，とりわけ中山間地域において大切なすの は, テレビ共同受信施設, 文化・レクリエーション施 設，近代的な賃貸住宅などがある. 賃貸住宅は新規参 入者などのほか, 農家の後継者であ都会的な生活ス夕 イルを希望する者には有効である. 一定年数経過後, 希望者には譲渡する自治体屯珍しくない。

第3 亿, 農家の農村定住を確保するため, 農業所得 向上対策に加えて農外所得向上対策が重要である. そ のためには道路網を整備充害して通勤圈を拡大し，企 業誘致などによって少なくとも通勤圈内に就業機会の 増加を図る必要がある18).

以上要するに集落営農の形成・持続的発展のために は, 各種農業政策に加えて総合的な地域政策を, 各種 農業政策之有機的に連携させて講じる必要がある. そ して，とりわけ中山間地域ではその必要性と緊急性が 高い.

\section{4. 集落営農の将来展望一むすびにかえて一}

\section{1）多様化する担い手の経営形態}

稲作など土地利用型農業の担い手の経営形態はすで に多様化しつつあるが，将来は一層の多様化が進むだ ろう．たとえば表 4 によると，現在の中心的担い手が 小規模農家である市町村は $84 \%$ と圧倒的に多く，大規 模農家・法人が $13.3 \%$ で続き, 生産組織・営農集団等 とその他は各 $1.3 \%$ できわめて少ない，それが，将来 「担うべき」形態では生産組織・営農集団等とその他 が大幅に増加し，両方で $51 \%$ に達している. 大規模農 家・法人も倍増するが $1 / 4$ 強である. 反対に小規模農 家は激減している.

このように市町村の担当者は構造変化を伴った担い 手の多様化を予測（期待む込められているのだろう） している，具体的には，家族経営の後退とそれ代わ る（あるいはそれを補完する）担い手として，家族経 
表 4 地域農業の担し手の現状と将来（稲作）

\begin{tabular}{c|c|c|c|c|c|c}
\hline & $\begin{array}{c}\text { 大規模農 } \\
\text { 家・法人 }\end{array}$ & $\begin{array}{c}\text { 小規模震家 } \\
\text { (青壮年男 } \\
\text { 子中心) }\end{array}$ & $\begin{array}{c}\text { 小規模農家 } \\
\text { (婦人・高 } \\
\text { 齢者中心) }\end{array}$ & $\begin{array}{c}\text { 生産組織、 } \\
\text { 棠農集団等 }\end{array}$ & その他 & 計 \\
\hline 現在 1 位 \{ & $\begin{array}{c}297 \\
(13.3)\end{array}$ & $\begin{array}{c}1,244 \\
(55.5)\end{array}$ & $\begin{array}{c}639 \\
(28.5)\end{array}$ & $\begin{array}{c}30 \\
(1.3)\end{array}$ & $\begin{array}{c}30 \\
(1.3)\end{array}$ & $\begin{array}{c}2,240 \\
(100.0)\end{array}$ \\
\hline 担うべき \{ & $\begin{array}{c}563 \\
(27.2)\end{array}$ & $\begin{array}{c}285 \\
(13.8)\end{array}$ & $\begin{array}{c}168 \\
(8.1)\end{array}$ & $\begin{array}{c}580 \\
(28.0)\end{array}$ & $\begin{array}{c}474 \\
(22.9)\end{array}$ & $\begin{array}{c}2,070 \\
(100.0)\end{array}$ \\
\hline
\end{tabular}

資料 : 農林統計協会『農業白書附属統計表 (平成 2 年度)』より引用.

注：1）原資料は農林水産省『農業の担い手の動向等に関する調査』(平成 2 年 9 月).

2）担い手の実態, 確保状況等を中心とした地域農業, 農村の動向に関し, 東京都特別区 を除く全市町村の農政・企画担当者を対象として実施したアンケート調査結果であり， 回答市町村数は 2,588 である.

3）「生産組織等」とは, 農作業の受託等を行う複数の農家からなる農業生産組織等であ る.

4)「その他」とは, 1〜数集落の範囲で共同で農作業等を行う集落営農, 農作業受託等 を行う農協や第 3 セクター等である。

5）上段は回答市町村数，下段は\%.

営の枠を超えた多椂な集団的担い手の形成が，基本的 な方向として展望されている. なかであ農協や第 3 七 クター等 (表 4 の注記参照) が将来の担い手として重 視されているのは注目される.

\section{2）集落営農の展開方向}

集落営農の展開方向を展望する場合の基本 的視点 は，農業労働力の不足と高齢化の進行を最大かつ直接 的契機とする家族経営の崩壊である，機珹作業中心の 部分委託から水管理など栽培管理を含む経営委託へ進 む農家が急増することは間違いない。

まず第 1 亿，集落営農の経営形態の展開方向を展望 すると，1つは生産組織型加引主として協業経営型へ の転換である，家族経営補完型の前者は, 補完すべき 家族経営の崩壊で，いわば存立基盤を失い必然的に変 貌せざるを得ない，多くは協業経営への転換が模索さ れ，一部は担い手が少なくて協業経営型が成り立たず に解体し, 特定農家による借地型自立経営の形成母体 になるむの, 農協・農業公社・第 3 七クターなど公的 な経営体を受皿に引き継がれるあのもでてくる．2つ は協業経営型自体の変貌で, たとえば参加農家の階層 分化にによる全員出役型加ら次第に専業農家型への純 化 ${ }^{19)}$ ，米の販売主体・農地利用権問題などへの対処や より近代的・企業的な経営形態を目指して任意組合加 ら農業生産法人（農事組合加有限会社加の選 択 屯 あ る)への転換が進む. また, 経営の管理運営面では, むらの論理・平等原則・地代重視から経営の論理・貢 献原則・労働重視へと, より企業的な管理システムへ の転換が求められる.

第 2 亿，地域別展開方向を簡単に展望する．まず都
市的農業地域では, 農業生産環境が悪化しており, 農 地の農業利用之農外利用へのスプロール的転用が混在 し，若者はじめ学動の機会費用屯高く，耕作放棄地率 や不作付地率むむしろ中山間地域より高い，そして農 業集落そのあのが活とんご崩壞しているので，集落営 農の形成はむずかしいといえる. 反面，地代の急速な 低下ああり, 借地型自立経営農家ヤ広域的な農業サー ビス事業体が成立する可能性がある。

平地農業地域は集落の規模が大きく，集落機能も比 較的維持されており，相対的に最屯条件が揃ってい る，集落営農屯多様な形態が成立しており，今後は多 くの家族経営が崩壊する一方, 大区画围場整備などを 契機に上述の展開方向が展望される. 同時に借地型自 立経営農家形成の可能性屯高まろう。

中山間農業地域は総じて集落機能が弱体化または崩 壞しているが，農家率が高く潜在的には集落の連帯意 識が残っている、リーダ一や若者がいないため地域農 業再生の内発的エネルギーが采しく, 外部リーダーの 役割がとくに大きい地域である．大規模農家の形成は 難しく, 集落営農が主要な担い手になるが, 生産組織型 加出発するにしても家族経営の崩壊か激しく, 早晚 協業経営型への展開が必要になる. 集落の規模が小さ く，中心的担い手屯著しく不足しており複数集落での 組織化あ必要である．ただ，どうしても担い手確保が 困難な場合は，農協・農業公社・第 3 セクタ一などに 頼らざるを得なくなる．また，ての地域では集落営農 形成の放らいは今後も地域社会と生活の維持に力点が 置机る。

\section{3）「新政策」の農業経営体と集落営農}


表 5 稲作を主位とする農家以外の農業事業体

\begin{tabular}{|c|c|c|c|c|c|c|c|c|c|}
\hline & $2 h a$ 未満 & $2 \sim 5$ & $\sim 10$ & $10 \sim 20$ & $20 \sim 30$ & $30 \sim 50$ & $50 \sim$ & 計 \\
\hline $\mathrm{s}$ & 全 体 & $\begin{array}{c}236 \\
(45.2)\end{array}$ & $\begin{array}{c}72 \\
(13.8)\end{array}$ & $\begin{array}{c}73 \\
(14.0)\end{array}$ & $\begin{array}{r}81 \\
(15.5)\end{array}$ & $\begin{array}{c}35 \\
(6.7)\end{array}$ & $\begin{array}{c}14 \\
(2.7)\end{array}$ & $\begin{array}{c}11 \\
(2.1)\end{array}$ & $\begin{array}{c}522 \\
(100)\end{array}$ \\
\hline \multirow{2}{*}{$\mathrm{H}$. } & 全 & $\begin{array}{c}196 \\
(33.7) \\
\end{array}$ & & $(14.6)$ & & $(1.0)$ & $\begin{array}{c}25 \\
(4.3)\end{array}$ & $\begin{array}{c}17 \\
(2.9)\end{array}$ & $\begin{array}{c}582 \\
(100)\end{array}$ \\
\hline & $\begin{array}{l}\text { うち協 } \\
\text { 業経営 }\end{array}$ & $\begin{array}{c}133 \\
(28.2) \\
\end{array}$ & $\begin{array}{r}89 \\
(18.9) \\
\end{array}$ & $\begin{array}{r}75 \\
(15.9) \\
\end{array}$ & $\begin{array}{c}104 \\
(22.1)\end{array}$ & $\begin{array}{c}36 \\
(7.6) \\
\end{array}$ & $\begin{array}{c}21 \\
(4.5) \\
\end{array}$ & $\begin{array}{c}13 \\
(2.8) \\
\end{array}$ & $\begin{array}{c}471 \\
(100) \\
\end{array}$ \\
\hline
\end{tabular}

資料 : 各年次センサス上作り成。

注：1）収穫面積規模別である.

2） 単位は事業体数. カッコ内は構成此 (\%).

「新政策」は10年程度後の稲作中心の望ましい経営 体像之形成目標数を明確に示している. ただ，現状と のギャップが極めて大きく，どのような対策を講じて 実現するのかか問題である.

「個別経営体」は田面積 5 ha以上の農家を 15 万戸形 成するが, 現在水稲収穫面積 5 ha以上の農家は全国に 15,695戸（都府県 5, 480戸）しかない（1990年センサ ス). 大部 分が現在の中核農家からの発展と考え，加 りに基幹男子農業専従者を 1 户 1 人として平均 30 年市 イクルであ, 毎年約 5,000 人の新規就農者を確保しな くてはならない20).「個別経営体」形成には，公的機 関が農地を委託農家から一元的に集積し, それを団地 化して担い手農家にまとめて貸付けるシステム整備な どの支援策が必要である.

「組織経営体」は本報告の集落営農之ほぼ同じ性格 のものが想定されている. 統計的には表 5 の農業事業 体がそれに該当するが，集落を基礎にしたものの数は わからない，表 5 の農業事業体数は目標の 2 万集団に 比べてきわめて少数であり，「新政策」が目指す 35 〜 $50 \mathrm{ha}$ （水稲収穫面積は25～35haだろう）規模のものは とくに少ない. 表 2 の集落営農型は約 $20 \mathrm{ha}$, 都府県の 1 集落当たり規模が農家28戸，田の面積18.7haである ことから，もう少し小規模な「組織経営体」の形成を 目指すべきである.いずれにせよ, 前述の戦略的課題 の実行や水稲生産組織など生産組織型集落営農からの 転換が重要なカギになる。

\section{4) 総 括}

農業労働力の絶対的不足と高龄化による家族経営の 崩壊が進行するなかで, 農地用役市場は供給過剩・地 代低下傾向が強まり農業構造変化の可能性が高まる. したがって後継者受皿として多様な経営体を準備する ととも可能になる，そして結局は，それらの経営体が 後継者にとって魅力的な要件を備えられるか, そうし
た経営体形成の戦略的課題がどれだけ実行できるかに 氻っている.

集落営農の形成・発展には実に多くの関係者による 莫大なエネルギーの投入之相応の財政支援が必要であ る.それであ集落営農があたらす経済的，社会的・公 益的意義は大きく, 家族経営に比べて後継者を幅広く 確保できるなどの利点もあり, その形成・発展を推進 しなくてはならない.

ただ，中山間地域などでリーダーやオペレーターが なく，外部リーダーが働きかけてあ集落営農形成の見 込みがないところでは, 当然大規模農家の形成屯困難 で, 農協・農業公社・第 3 セクターなどによる対応が 必要になるう。

一方，農地用役市場の買手市場化が進むと，農地を 大量に集積して団地化し，団地単位に貸付を翰旋する 公的システムを作れば，借地型自立経営農家形成の可 能性は大いに高まる．借地分散の慗害を克服していわ ゆる10haの壁を破り, 集落営農などに比へて優る経営 管理運営面での機動性・柔軟性などを生かした企業的 家族経営の展開も期待できる. ただ，用排水路・農道 等の公的管理システム ${ }^{21)}$ (費用負担を含めた) の形成 が課題になる。

「新政策」の経営体形成目標の実現には, 農業構造 変化の条件は整いつつあるが現状とのギャップが大き く, 相当の政策支援と地域の主体的努力が必要であ る、なお，「新政策」がいま 1 つ迫力と説得力を欠く のは，たとえば食料自給率目標とその実現計画の明示 といった，国策としての農業・食料政策の基本理念が 不明確だからである．乙の基本理念が明確にされない と, 若い後継者の確保はますます困難になる，また， 本報告の考察はすべて米の国内完全自給及び現状程度 の米価水準を前提にしているととを付言しておきた い. 
注 1）厳密には集落営農集団とか集落営農組織などと 記すべきであろうが，簡単化して集落営農と記す。 2）詳しい定義等は, 拙稿「農業の担い手としての 集落営農」『農林業問題研究』第28巻 2 号, 1992 年 6 月, 36 頁, 参照.

3）稲本志良は集団経営を法人協業経営と任意協業 経営に区分している。稲本志良「大規模水田農業 経営の成立・発展と農業法人の現代的意義」『農 林業問題研究』第 26 巻第 3 号, 1990年 9 月, 2 頁, 参照.

4) 農林統計協会『農業白書附属統計表（平成 2 年 度)』1991年 4 月，132頁。

5 ）農林統計協会『農業白書附属統計表（平成 3 年 度)」1992年 6 月，153頁.

6)その主な理由は借地を含む経営地の分散にあ る。例えば稲本志良『農業の技術進歩と家族経営』 大明堂, 1987年 1 月, 213 頁, 参照. 他飞『大規模 稲作農家の技術之経営』農業研究センタ一研究資 料第 17 号, 1989年 3 月, 参照.

7）下村義人む「集団的営農」の存立基礎として集 落を強調している. 下村義人『集団的営農の計画 之管理』明文書房, 1989年 6 月, $6 \sim 7$ 頁, 参照. また，1990年センサスによると集団的土地利用方 式で集団転作に取り組えだ集落数は，全国で 26 , 007 (全集落の18.6\%) あり，取り組んだ笔囲は 「集落の一部」が43.6\%，「集落全体」が40.2\%, 「複数集落」が $16.2 \%$ とほとんどが「集落」が単 位である。農林水産省『片ット農林水産 統 (平成 3 年度版)』107頁, 参照.

8）前揭把稿， 40 頁を参考にした。

9）ただ，たとえば米生産費低減を短絡的に米価引 き下げにつなげると，担い手は育たなくなる恐れ があり，第 1 之第 2 の目的・必要性は実現がむず かしくなる。例えば拙稿「地域農業の担い手育成 をどう進めるか」農業と経済（臨時增刊号）」第 57 巻第 6 号, 1991年 5 月, 参照.
10）前揭注2)拙稿， 38〜 39頁を参考にした。

11）との点は例えば嘉田良平「農業構造政策の経済 理論」(賴平編『農業政策の基礎理論」家の光協 会, 1987年11月, 所収), 275頁, 参照.

12）前揭注2)拙稿，39頁を参考にした。

13）農業白書（平成 2 年度）によると，平成元年の 水田小作料は昭和 62 年に比べ全国で $6.1 \%$ 下落し, 田の標準小作料は平成元年の改訂で昭和 61 年に比 べて全国平均 $6.2 \%$ (暫定値)の引き下げとなっ た.

14）原資料は農林水産省『農業の担い手の動向等に 関する調查』1990年 9 月，である。

15）詳しくは例えば拙稿「中山間地域農業振興の方 向之課題」(賴平編著『国際化時代の農業経済学」 富民協会, 1992年 3 月, 所収), 228頁, 参照.

16）具体的な事例として拙稿「Uターン就農者のプ 口農業者への道」『農業之経済」第 56 巻第 5 号, 1990年 5 月, 参照.

17）詳しくは前揭注15）拙稿, 226頁, 参照.

18）その他, 農業を核にした新しい地域産業の形成 あ重要である。前揭注15）拙稿, 223 頁, 参照.

19）その過程で構成員の中心は, 後継者としての若 者をはじめ農家から人に移るだろう。

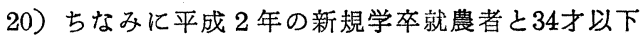
の離職就農者は、それぞれ1.8千人，1.9干人であ る. 『前揭書, 注5)』, 133頁.

21）これは集落営農が専業農家型に純化した場合に あ同様に必要である.

(謝辞) 大会シンポジゥムでは大原興太郎, 山本 修, 波多野忠雄, 新山陽子の各氏から貴重なコメン 卜をいただいた，記して謝意を表する次第であ る。

（筆者：島根大学農学部） 